\title{
Frequência do grupo sanguíneo DEA 1.1 em cães atendidos no Hospital Veterinário da UFMT (Sinop/MT), risco de sensibilização de cães DEA 1 negativos e da ocorrência de reação transfusional hemolítica por ocasião de uma segunda transfusão de sangue*
}

\author{
DEA 1.1 blood group frequency in dogs attended at the veterinary \\ hospital of UFMT (Sinop/MT), risk of DEA 1 negative dog sensitization and \\ occurrence of hemolytic transfusion reaction in a second blood transfusion
}

\author{
Adriana Alonso Novais, ${ }^{* *}$ Helena de Freitas Magron, ${ }^{* * *}$ Alessandra Kataoka, ${ }^{* * * *}$ Darlan Henrique Canei, ${ }^{* * *}$ \\ Jeana Pereira da Silva, ${ }^{* * *}$ Ana Lucia Vasconcelos ${ }^{* * * *}$
}

\begin{abstract}
Resumo
Objetivou-se identificar a frequência do grupo sanguíneo DEA 1.1 em cães de Sinop, Mato Grosso, Brasil, para auxiliar a seleção de doadores e receptores de sangue compatíveis e, adicionalmente, avaliar o risco de reações transfusionais em cães sensibilizados. Além disso, a partir dos resultados obtidos, selecionar potenciais doadores de sangue para compor um banco de dados. Um total de 195 cães adultos (de 1 a 4 anos de idade), machos e fêmeas, mestiços e puros, que nunca haviam recebido transfusões de sangue, foram triados no Hospital Veterinário da Universidade do Mato Grosso. A tipagem sanguínea DEA 1.1 foi realizada utilizando-se ensaio imunocromatográfico comercialmente disponível para DEA 1.1 (Quick Test DEA 1.1, Alvedia, Lyon, França). Os resultados demonstraram uma frequência geral de $65 \%$ para cães DEA 1.1 positivos $(n=126)$ e $35 \%$ para cães DEA 1 negativos $(n=69)$. O risco geral de sensibilização de cães DEA 1 negativos após uma primeira transfusão com sangue DEA 1.1 positivo foi calculado em $23 \%$, enquanto o risco deste receptor sensibilizado receber sangue DEA 1.1 positivo em uma segunda transfusão e desenvolver uma reação hemolítica aguda foi calculado em $5 \%$. A tipagem sanguínea dos cães permitiu sua inserção como doadores de sangue tipados para o grupo DEA 1 em um banco de dados preliminar e garantiu a segurança das transfusões de sangue.
\end{abstract}

Palavras-chave: tipagem sanguínea canina, imunohematologia, medicina transfusional.

\begin{abstract}
The goal of this research was to identify the frequency of the DEA 1.1 blood group in dogs from Sinop, Mato Grosso, Brazil, to help in the recruitment of compatible blood donors and recipients, and to assess the risk of transfusion reactions in previously sensitized dogs. Also, from the obtained results, to pick potential blood donors to compose a data bank. 195 adult dogs (1 to 4 years old), males and females, mongrel and purebred dogs were screened at the Veterinary Hospital of the University of Mato Grosso. The DEA 1.1 blood typing was performed using commercially available immunochromatographic strip for DEA 1.1 (Quick Test DEA 1.1, Alvedia, Lyon, France). The results showed a general frequency of $65 \%$ for DEA 1.1 positive dogs $(n=126)$ and $35 \%$ for DEA 1 negative dogs $(n=69)$. The general risk of sensitization of a DEA 1 negative dog following a first transfusion with DEA 1.1 positive blood was $23 \%$, while the risk of this sensitized recipient to receive DEA 1.1 positive blood in a second transfusion and to develop an acute hemolytic reaction was calculated to be $5 \%$. The blood typing of the dogs allowed their classification as DEA 1 typed blood donors, in a preliminary data bank, and also ensured the safety of blood transfusions.
\end{abstract}

Keywords: canine blood typing, immunohematology, transfusion medicine.

\section{Introduction}

Currently, blood transfusions are increasingly common in veterinary medicine and are often used in emergency and surgical procedures. In these cases, it is necessary to know about blood types and to use specific tests to avoid transfusion reactions. Not all antigens are considered to be potentially important with regard to their ability to trigger a transfusion

${ }^{*}$ Recebido em 29 de janeiro de 2019 e aceito em 8 de junho de 2019.

**Docente responsável pela disciplina de Clínica Médica e Terapêutica de Cães e Gatos do Curso de Medicina Veterinária da UFMT, Campus de Sinop, MT, Brasil; autor para correspondência: aanovais@terra.com.br;

***Acadêmico(a) do Curso de Medicina Veterinária da UFMT, Campus de Sinop, MT, Brasil;

****Docente responsável pela disciplina de Patologia Clínica Veterinária do Curso de Medicina Veterinária da UFMT, Campus de Sinop, MT, Brasil;

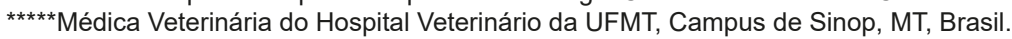


reaction, but among them, the DEA 1.1 is the most antigenic and, thus, it becomes the major responsible for triggering an acute hemolytic transfusion reaction in dogs. Fortunately, several commercial kits for typing DEA 1.1 antigen have been developed (Tocci, 2010; Novais e Magron, 2018).

The blood types of domestic dogs were standardized as Dog Erythrocyte Antigen (DEA), which include seven blood groups named DEA 1, DEA 3, DEA 4, DEA 5, DEA 6, DEA 7 and DEA 8 (Vriesendorp et al., 1976; Symons \& Bell, 1991; Bull, 1992; Hale, 1995). However, other erythrocyte antigens have been described up to date, but are not internationally standardized, such as Dal and Kai 1 and Kai 2 (Blais et al., 2007; Kessler et al., 2010; Euler et al., 2016; Lee et al., 2017).

While most blood group systems in dogs are thought to be simple 2 allele systems with a positive and negative blood type, the DEA 1 blood group system differs. Based upon 2 polyclonal typing reagents (anti-DEA 1.1 and $1 . X$ ) raised in dogs, the DEA 1 system includes at least 2 types, DEA 1.1 and DEA 1.2. The DEA 1.1 antigen appears to be dominant to DEA 1.2, such that only a dog that is DEA 1.1- can be DEA 1.2+. In addition, a DEA $1.3(\mathrm{~A} 3)$ antigen has been proposed in 1 study, but reagents are not available for further comparison. The prevalence of DEA $1.1+$ dogs varies both geographically and among breeds from $100 \%$ to $<10 \%$, but has been estimated by approximately $50 \%$ overall internationally (Symons and Bell, 1991; Blais et al., 2007; Riond et al., 2011).

The DEA 1 system is considered the most important with regard to blood transfusions. The natural antibodies against this group have not been documented, so that reactions do not occur in the first transfusion. Nevertheless, once sensitized in previous transfusions, patients may develop severe hemolytic reactions after a subsequent incompatible transfusion (Hale, 1995; Kessler et al., 2010). The prevalence for DEA 1.1 blood group was described by authors from different countries (Tab. 1).

Table 1: General frequency of DEA 1.1 canine erythrocyte antigens in dogs from different countries, according to the consulted literature

\begin{tabular}{lccc}
\hline \multicolumn{1}{c}{ Author } & Country & $\begin{array}{c}\text { Number } \\
\text { of dogs }\end{array}$ & $\begin{array}{c}\text { \% DEA 1.1 } \\
\text { positive }\end{array}$ \\
\hline Swisher \& young (1961) & USA & 332 & 40 \\
Suzuki et al. (1975) & USA & 217 & 36 \\
Ejima et al. (1986) & Japan & 545 & 44 \\
Giger et al. (1995) & USA & 224 & 33 \\
Novais et al. (1996) & Brazil & 150 & 51 \\
Van der Merwe (2002) & South Africa & 233 & 47 \\
Novais et al. (2004) & Brazil & 200 & 60 \\
Vilar (2006) & Brazil & 72 & 69 \\
Ferreira et al. (2011) & Portugal & 274 & 57 \\
Esteves et al. (2011) & Brazil & 100 & 61 \\
Riond et al. (2011) & Switzerland & 304 & 53 \\
Souza et al. (2014) & Brazil & 300 & 53 \\
Valentin et al. (2017) & Italy & 7.414 & 61 \\
\hline
\end{tabular}

The present study aimed to identify the frequency of the DEA 1.1 blood group in dogs from Sinop, Mato Grosso, Brazil, according to the racial groups, once this knowledge could be a very important tool for the recruitment of typed compatible blood donors and recipients. Also, to assess the risk of transfusion reactions in previously sensitized dogs. Additionally, from the results obtained with blood typing, to pick potential blood donors to compose a data bank.

\section{Material and methods}

A total of 195 adult dogs (1 to 4 years old), males and females, mongrel and purebred dogs, ages between 1 and 8 years, who had never received blood transfusions, were screened at the Veterinary Hospital of UFMT (University of Mato Grosso), Sinop, Mato Grosso, Brazil. Four $\mathrm{mL}$ samples for blood typing were obtained from jugular or cephalic vein of the dogs, using a $23 \mathrm{G}$ needle connected to a $3 \mathrm{~mL}$ syringe. The blood was transferred to 4,0 mL EDTA-anticoagulated tube (BD Vacutainer $\left.{ }^{\circledR}\right)$ and it was stored between 1 and $4^{\circ} \mathrm{C}$. The DEA 1.1 blood typing was performed using commercially available immunochromatographic strip for DEA 1.1 (Quick Test DEA 1.1, Alvedia, Lyon, France), according to the manufacturer's instructions as already described (Seth et al., 2012).

The general risk of sensitization and the risk of sensitization for each breed in a first random transfusion was calculated multiplying the obtained DEA 1.1 positive and DEA 1 negative frequencies in the following formula (\% DEA 1 negative $x \%$ DEA 1.1 positive)/100. Next, the first result was multiplied in another formula (\% DEA 1 negative $\mathrm{x} \%$ DEA 1.1 positive) $\mathrm{x}$ $\%$ sensitization for the first transfusion) $/ 10.000$, to obtain the potential risk for an acute hemolytic transfusion reaction to occur in a second incompatible random transfusion (Novais et al., 1999; Ferreira et al., 2011; Spada et al., 2016; Valentin et al., 2017). This research was approved by CEUA (Ethics Committee on Animal Research) under the number 23108.781760/12-0. Results were analyzed by descriptive statistical and probabilistic analysis.

\section{Results and discussion}

Among the 195 dogs submitted to the blood typing test, it was found a general frequency of $65 \%$ for DEA 1.1 positive dogs ( $n$ $=126$ ) and $35 \%$ for DEA 1 negative dogs $(n=69)$. The dogs were grouped according to the breed (Tab. 2) in order to verify differences for the 1.1 frequency in each group.

The obtained general frequency was similar to those frequencies described by Novais et al. (2004), Vilar (2006) and Esteves et al. (2011) in Brazil, and Valentin et al. (2017) in Italy. The latter research is relevant because of the expressive number of tested dogs $(7,414)$. The same authors found $64,7 \%$ positivity for DEA 1.1 blood group among mongrel dogs, what is similar to this research finding (67\%) and other authors' results (Ferreira et al., 2011; Souza et al., 2014). The obtained DEA 1.1 frequency for German Shepherds and Dobermans was 50\%, but Valentin et al. (2017), Milczak et al. (2016) and Souza et al. (2014) described a low frequency of DEA 1.1 positive dogs among German Shepherd (18,9\%, 15\% and 20\%, respectively). Also, Van der Merwe et al. (2002) have also described a low frequency (less than $20 \%$ ) of DEA 1.1 positive dogs among German Shepherds

R. bras. Ci. Vet., v. 26, n. 2, p. 51-54, abr//un. 2019 
Table 2: Blood typing results for the DEA 1.1 blood group, according to the racial group $(n=195)$ (Sinop, Mato Grosso, Brazil, 2018)

\begin{tabular}{lcccccc}
\hline Racial Group & $\mathbf{n}$ & $\mathbf{\%}$ & Pos $\mathbf{~}$ & $\begin{array}{c}\text { Pos } \\
\text { \% }\end{array}$ & Neg n & $\begin{array}{c}\text { Neg } \\
\text { \% }\end{array}$ \\
\hline Mongrel dogs & 88 & 45,1 & 59 & 67 & 29 & 33 \\
Pitbull & 33 & 16,9 & 16 & 48 & 17 & 52 \\
Rottweiler & 12 & 6,2 & 11 & 92 & 1 & 8 \\
Australian cattle dog & 10 & 5,1 & 4 & 40 & 6 & 60 \\
Border collie & 10 & 5,1 & 6 & 60 & 4 & 40 \\
Boxer & 10 & 5,1 & 3 & 30 & 7 & 70 \\
Dalmatian & 7 & 3,6 & 7 & 100 & 0 & 0 \\
Labrador retriever & 7 & 3,6 & 6 & 86 & 1 & 14 \\
Doberman pinscher & 4 & 2,1 & 2 & 50 & 2 & 50 \\
Siberian husky & 3 & 1,5 & 3 & 100 & 0 & 0 \\
Chow chow & 2 & 1,0 & 2 & 100 & 0 & 0 \\
Maremma sheepdog & 2 & 1,0 & 1 & 50 & 1 & 50 \\
German shepherd dog & 2 & 1,0 & 1 & 50 & 1 & 50 \\
Bernese shepherd dog & 1 & 0,5 & 1 & 100 & 0 & 0 \\
Brazilian mastiff & 1 & 0,5 & 1 & 100 & 0 & 0 \\
Golden retriever & 1 & 0,5 & 1 & 100 & 0 & 0 \\
Shar-pei & 1 & 0,5 & 1 & 100 & 0 & 0 \\
Swiss shepherd & 1 & 0,5 & 1 & 100 & 0 & 0 \\
Total & $\mathbf{1 9 5}$ & $\mathbf{1 0 0}$ & $\mathbf{1 2 6}$ & $\mathbf{6 5}$ & $\mathbf{6 9}$ & $\mathbf{3 5}$ \\
\hline
\end{tabular}

and Boxers, corroborating Valentin et al. (2017) results, and a high frequency (greater than $75 \%$ ) in Rottweilers and Dalmatians. In the present study we found $30 \%$ positivity among Boxers, while $92 \%$ of positivity in Rottweilers and $100 \%$ of positivity for DEA 1.1 blood group in Dalmatian dogs, corroborating last authors' results. Riond et al. (2011) also described all tested Boxers were negative for DEA 1 group, corroborating the results of Ferreira et al. (2011). They also described that all Bernese mountain dogs and Rottweilers tested positive for DEA 1.1. In the present research, only one Bernese mountain dog was typed and was positive for DEA 1.1. However, among tested Rottweilers it was found $92 \%$ of dogs positive for DEA 1.1 group, while Ferreira et al. (2011) described $88 \%$ of positivity, Souza et al. (2014) and Valentin et al. (2017) described $80 \%$ and $89,5 \%$ of Rottweilers, respectively, were positive for DEA 1.1. In the present study it was found $40 \%$ of Border Collies positive for DEA 1.1 blood group, what is similar to Valentin et al. (2017) results, but different from the results of Riond et al. (2011), that described all tested Border Collies were negative for DEA 1.1. Those blood typing prevalence differences between all of the dog racial groups could be explained by diverse genetic pools of ancestors and different levels of inbreeding among different geographic locations.

The general probability of sensitization, following a first transfusion with DEA 1.1 positive blood in a DEA 1 negative recipient, was calculated in $23 \%$, while the probability of this sensitized recipient to receive DEA 1.1 positive blood in a second transfusion and to develop an acute hemolytic reaction was calculated to be $5 \%$. While Rottweilers and Dalmatians are less susceptible to this sensitization, due to the high DEA 1.1 frequency, Boxers are more susceptible to it, due to the low DEA 1.1 frequency (Tab. 3).

In what concerns to blood transfusion, at UFMT veterinary hospital, the obtained low prevalence of DEA 1.1 blood group among tested Boxers make them the best blood donor between studied breeds, because of their lowest probability of DEA 1 negative recipient's sensitization. After Boxers, Australian Cattle Dogs and Pitbulls can be better blood donors for the same reason, while Rottweilers and mongrel dogs are worse blood donors because of their high prevalence for DEA 1.1 positive blood.

Table 3: Probability of sensitization of a DEA 1.1 negative dog, after a first random transfusion of untyped blood and probability of an acute hemolytic reaction during a second transfusion with blood from the same racial group $(n=195)$ (Sinop, Mato Grosso, Brazil, 2018)

\begin{tabular}{lcc}
\hline Breed & $\begin{array}{c}\text { Probability of } \\
\text { sensitization } \\
\text { after a first } \\
\text { transfusion }\end{array}$ & $\begin{array}{c}\text { Probability of } \\
\text { hemolytic reaction } \\
\text { in a second } \\
\text { random transfusion }\end{array}$ \\
Mongrel dogs & $22 \%$ & $4.9 \%$ \\
Pitbull & $25 \%$ & $6.2 \%$ \\
Rottweiler & $8 \%$ & $0.6 \%$ \\
Australian cattle dog & $24 \%$ & $5.8 \%$ \\
Border collie & $24 \%$ & $5.8 \%$ \\
Boxer & $21 \%$ & $4.4 \%$ \\
Dalmatian & $0 \%$ & $0.0 \%$ \\
Labrador retriever & $12 \%$ & $1.5 \%$ \\
Doberman pinscher & $25 \%$ & $6.3 \%$ \\
Siberian husky & $0 \%$ & $0.0 \%$ \\
Chow chow & $0 \%$ & $0.0 \%$ \\
Maremma sheepdog & $25 \%$ & $6.3 \%$ \\
German shepherd dog & $25 \%$ & $6.3 \%$ \\
Bernese shepherd dog & $0 \%$ & $0.0 \%$ \\
Brazilian mastiff & $0 \%$ & $0.0 \%$ \\
Golden retriever & $0 \%$ & $0.0 \%$ \\
Shar-pei & $0 \%$ & $0.0 \%$ \\
Swiss shepherd & $0 \%$ & $0.0 \%$ \\
\hline
\end{tabular}

The high prevalence of the DEA 1.1 erythrocyte antigen, considered to be the most antigenic in this species, increases the transfusional sensitization risk of negative dogs. On the other hand, it reduces the probability of finding DEA 1 negative dogs, what may represent a favorable factor for canine patients treated in our country, where most blood transfusions are still made at random. That could explain the low incidence of acute hemolytic transfusion reactions observed at our Veterinary Hospital. On the other hand, the difficulty to find DEA 1 negative dogs makes it difficult to obtain the ideal blood donor. 


\section{Conclusions}

In conclusion, tested breeds were found to differ considerably in the frequency of DEA 1.1 blood group and, also, to differ between the same breed for dogs from different countries, corroborating the findings of consulted literature. The general risk of sensitization of recipient dogs following a first transfusion with DEA 1.1 positive blood in a DEA 1 negative recipient was calculated in $23 \%$, while the risk of this sensitized recipient to receive DEA 1.1 positive blood in a second transfusion and to develop an acute hemolytic reaction was calculated to be $5 \%$. Although this can be considered a low probability, donors and recipients should be typed for DEA 1.1 blood group in order to avoid sensitization of DEA 1 negative dogs after receiving DEA 1.1 positive blood transfusions. The blood typing of the dogs allowed their classification in DEA 1.1 positive and DEA 1 negative types, in a preliminary blood transfusion data bank.

\section{Acknowledgments}

The authors are grateful to FAPEMAT (Research Foundation of Mato Grosso) that gave the financial support for this project.

\section{References}

BLAIS, M.C.; BERMAN, L.; OAKLEY, D.A. et al. Canine Dal blood type: a red cell antigen lacking in some Dalmatians. Journal of Veterinary Internal Medicine, vol. 21, no. 2, pp. 281- 286, 2007.

BULL, R.W. Inmunohematología. In: Halliwell, R. E. W. \& Gorman, N. T. (Ed.) Inmunologia clinica veterinaria, Zaragoza: Editorial Acribia S. A, 1992.

EJIMA, H.; KUROKAWA, K.; IKEMOTO, S. Phenotype and gene frequency of red blood cell groups in dogs of various breeds reared in Japan. Jpn. J. Vet. Sci. , v. 48, p. 363-368, 1986.

ESTEVES, V.S.; LACERDA, L.A.; LASTA, C.S. et al.. Frequencies of DEA blood types in a purebred canine blood donor population in Porto Alegre, RS, Brazil. Pesq. Vet. Bras. 31(2):178-181, 2011.

EULER, C.C.; LEE, J.H.; KIM, H.Y. et al.. Survey of two new (Kai 1 and Kai 2) and other blood groups in dogs of North America," J. Vet. Int. Med., vol. 30, no. 5, pp. 1642-1647, 2016.

FERREIRA, R.R.; GOPEGUI, R.R.; MATOS, A.J. Frequency of dog erythrocyte antigen 1.1 expression in dogs from Portugal. Vet. Clin. Pathol., v. 40, n. 2, p. 198-201, 2011.

GIGER, U.; GELENS, C.J.; CALLAN, M.B et al. An acute hemolytic transfusion reaction caused by dog erythrocyte antigen 1.1 incompatibility in a previously sensitized dog. JAVMA, v.206, n. 9, p. 1358-1362, 1995.

HALE, A.S. Canine blood groups and their importance in veterinary transfusion medicine. In: KRISTENSEN \& FELDMAN (Ed.). The Vet. Clin. of North Am. - Small Anim. Pract., v. 25, n. 6, p. 1323-32, 1995.

KESSLER, R.J.; REESE, J.; CHANG, D. et al.. Dog erythrocyte antigens 1.1, 1.2, 3, 4, 7 and Dal blood typing and cross-matching by gel column technique. Vet. Clin. Path., vol. 39, n. 3, p. 306-316, 2010

LEE, J. H.; GIGER, U.; KIM, H. Y. Kai1 and Kai 2:

Characterization of these dog erythrocyte antigens by monoclonal antibodies. PLOS ONE| https://doi.org/10.1371/journal. pone.179932 June 29, 2017.

MILCZAK, A.; ABRAMOWICZ, B.; MADANY, J. et al. Frequency of dea 1.1 antigen in german shepherds. Scientific Messenger LNUVMBT named after S. Z. Gzhytskyj, v. 18, n. 3, 2016.

NOVAIS, A.A.; SANTANA, A.E.; VICENTIN, L.A. Prevalência do grupo sanguíneo DEA 1 (subgrupos 1.1 e 1.2) em cães criados no Brasil. Braz. J. Vet. Res. Anim. Sci., v. 36, p. 23-27, 1999.

NOVAIS, A.A.; SANTANA, A.E.; FAGLIARI, J.J. Prevalência dos antígenos eritrocitários caninos em cães domésticos (Canis familiaris) e investigação dos parâmetros hematológicos e da ocorrência de antígenos eritrocitários em lobos-guará (Chrysocyon brachyurus) e cachorros-do-mato (Cerdocyon thous) criados no Brasil. ARS Veterinária, v. 20, p. 212-218, 2004.
NOVAIS, A.A.; MAGRON, H.F. Canine blood groups: a review. Scientific Electronic Archives, Issue ID: Sci. Elec. Arch. Vol. 11 (5), 2018. Article link http://www.seasinop.com.br/revista/index. A\&pa ge=article\&op=view\&path\%5B \%5D=761\&path\%5B\%5D=pdf

RIOND, B.; SCHULER, E.; ROGG, E. et al.. Prevalence of dog erythrocyte antigen 1.1 in dogs in Switzerland evaluated with the gel column technique. Schweiz Arch Tierheilkd, v. 153, n. 8, p. 369-374, 2011.

SETH, M .; JACKSON, K.V.; WINZELBERG, S. et al. Comparison of gel column, card, and cartridge techniques for dog erythrocyte antigen 1.1 blood typing. Am J Vet Res, v. 73, p. 213-219, 2012.

SOUZA, S.L.; STOPIGLIA, A.J.; GOMES, S.G.R. et al. Estudo da frequência dos antígenos eritrocitários caninos 1, 1.1 e 7 e risco de transfusão incompatível em cães de diferentes raças e mestiços da região metropolitana da cidade de São Paulo, SP, Brasil. Braz. J. Vet. Res. Anim. Sci., São Paulo, v. 51, n. 4, p. 316323, 2014

SPADA, E.; PROVERBIO, D.; FLÓREZ L.M.V. et al. Prevalence of Dog Erythrocyte Antigens 1, 4, and 7 in Podenco Ibicenco (Ibizan Hounds) from Ibiza Island. Vet Med Int . 2016; 2016: 1048257. doi: 10.1155 / 2016/1048257

SUZUKI, K. et al. New antibodies in dog blood groups. Transplantation Proccedings, v. 7, n. 3, p. 365-367, 1975.

SWISHER, S.N.; YOUNG, L.E. The blood grouping systems of dogs. Physiol. Rev., Bethesda, v. 41, p. 495-520, 1961.

SYMONS, M.; BELL, K. Expansion of the canine A blood group system. Anim. Genet., Oxford, v. 22, p. 227-235, 1991.

TOCCI, L. J. Transfusion Medicine in Small Animal Practice. Veterinary Clinics of North America, Small Animal Practice. Philadelphia, v. 40, p. 485-494, 2010.

VALENTIN, A.A.M.; GAVAZZA, A.; LUBAS, G. Prevalence of dog erythrocyte antigen 1 in 7,414 dogs in Italy. Vet. Med. Int. Published online 2017 Sep 24, doi: 10.1155/2017/5914629. https://www.ncbi.nlm.nih.gov/pmc/articles/PMC5632924/

VAN DER MERWE, L.L.; JACOBSON, L.S.; PRETORIUS, G.J. The breed prevalence of dog erythrocyte antigen 1.1 in the Onderstepoort área of South Africa and its significance in selection of canine blood donors. J. S. Afr. Vet. Assoc., v. 73, n. 2, p. 53-56, 2002.

VILAR, T.D. Tipagem sanguínea em cães. Nosso Clínico, Ano IX, n. 53, p 38-42, 2006.

VRIESENDORP, H.M.; Albert, E.D.; Templeton, J.W. et al. Joint Report of the Second International Workshop on Canine Immunogenetics. Transplant. Proc., v. 8, p. 289-314, 1976. 